\title{
Література:
}

1. De Bruyn A., Alvarez A.P., Sandra P., De Leenheer L. O- $\beta$-Dfructofuranosyl-( $2 \rightarrow 1)$-O- $\beta$-D-fructofuranosyl-( $2 \rightarrow 1)$-D-fructose, a product of the enzymic hydrolysis of the inulin from Cichorium intybus // Carbohydr. Res.-1992.-Vol.235.

2. C.Е. Траубенберг, Пищевая химия (Углеводы, минеральные вещества, вода). / Траубенберг С.Е., Осташенкова Н.В., Вяльцева И.В., Кобелева И.Б. и др. - М. : Изд.комплекс МГУПП, 2003.

3. Вагабов М.В., Мангуева 3.М., Мурзаева П.Д. Оптимизация ферментативного процесса гидролиза инулина из топинамбура. // Вестник ДГТУ. - 2007. - № 12.

DOI https://doi.org/10.30525/978-9934-588-79-2-2.22

\section{ДОСЛІДЖЕННЯ СПОСОБІВ КОРЕКЦІЇ СЕЛЕНОДЕФІЦИТНИХ СТАНІВ ЛЮДИНИ}

Применко В. Г.

кандидат технічних наук,

завідувач кафедри менеджменту і адміністрування

Відокремленого підрозділу "Дніпровський факультет менеджменту

і бізнесу Київського університету культури»

Сефіханова К. А.

кандидат технічних наук,

декан

Відокремленого підрозділу "Дніпровський факультет менеджменту

i бізнесу Київького університету культури»

Щеньова В. Б.

кандидат технічних наук,

дочент кафедри менеджменту і адміністрування

Відокремленого підрозділу "Дніпровський факультет менеджменту

i бізнесу Київького університету культури»

$$
\text { м. Дніпро, Україна }
$$

Значний розвиток хімічної та харчової промисловостей спонукав до виникнення індустрії дієтичних добавок з метою збагачення продуктів на вітаміни, мінеральні речовини та інші харчові компоненти. Так, введення до складу добавок амінокислотних комплексів із селе88 
ном здатне підвищити опір організму захворюванням техногенного походження та покращити загальний стан здоров’я людини [1].

Нині досить інтенсивно ведуться роботи зі створення напівсинтетичних і синтетичних Se-вміщуючих лікарських субстанцій з активністю, що базується на природніх антиоксидантних, канцеропротекторних властивостях Se. Наразі, мова йде про ліки, а не про харчові та дієтичні добавки. Таких речовин сьогодні синтезовано доволі мало (рис.). Розглянемо деякі з них.

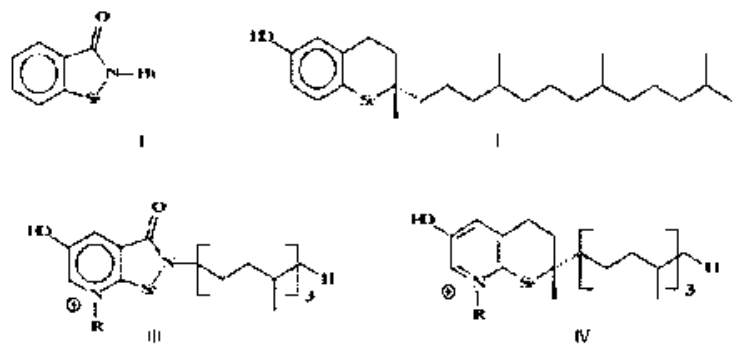

Рис. Синтетичні Se-вміщуючі лікувальні сполуки: I - ебселен; II - Sе-токоферол; III та IV - піридінісві аналоги Se-токоферолу

В молекулі Se-токоферолу (рис. II) лікувальну функцію крім фенольного гідроксилу (як це має місце у вітаміні Е) може виконувати і атом Se (своєю неподіленою електронною парою за дуже низького значенням іонізаційного потенціалу). Введення в такі структури піридинієвого фрагмента дозволяє варіювати ще й їх біфільну розчинність (рис. III, IV).

У випадках інтенсивного терапевтичного втручання (наприклад, при хіміотерапії раку потужними протипухлинними препаратами) застосування таких синтетичних Se-органічних сполук $є$ виправданим, оскільки вони діють більш ефективно за природні аналоги.

Нівелювання згубної дії регіонального гіпоселенозу на здоров'я людини можливе й через використання дієтичних, харчових добавок або введення Se в харчові продукти підвищеного попиту. Вони, як відомо, не $є$ лікарськими препаратами й відносяться до безрецептурних профілактичних засобів, які дозволяють наситити організм дефіцитними елементами їжі й, тим самим, зміцнити здоров'я. За даними Київського НДІ гігієни харчування, полівітамінно-мінеральні препарати, наприклад, щодня приймає не більше 3\% населення України, в той час як у Свропі - не менше $50 \%$, в США - $80 \%$. 
Людині доцільно вживати продукти, що містять нетоксичні органічні форми Se: зернові та продукти їх переробки, горіхоплідні, продукти тваринництва тощо. Але, беззаперечним $є$ той факт, що ситуація Se-дифіциту в Україні та світі має тенденцію до погіршення саме за рахунок зменшення кількості мікроелементу в грунтах $\mathrm{i}$, як наслідок, в продуктах рослинництва та тваринництва.

Тому, актуального значення набуває питання розробки технологій харчових та дієтичних добавок, збагачених на селен. На сьогоднішній день їх апробовано безліч. Детальний аналіз наукових, методичних та дослідних робіт вітчизняних і закордонних учених в галузі агрономії та сільського господарства, тваринництва та технології харчових продуктів дозволив згрупувати в порівняльній таблиці відомості про найбільш знані й уживані добавки (премікси) з Se.

Таблиця

Основні Se-вміщуючі дістичні добавки на ринку Украӥни

\begin{tabular}{|c|c|c|c|c|}
\hline № п/ா/ா & Найменування & Виробник & $\begin{array}{c}\text { Основна } \\
\text { хімічна форма Se }\end{array}$ & $\begin{array}{c}\text { Склад } \\
1 \text { таблетки }\end{array}$ \\
\hline 1 & Селен-актив & $\begin{array}{l}\text { ТОВ «Діод», } \\
\text { Москва }\end{array}$ & Селенопіран & $\begin{array}{c}50 \text { мкг Se } \\
50 \text { мкг вітаміну C }\end{array}$ \\
\hline 2 & Селен ЕС & $\begin{array}{c}\text { TОВ «Біокор-П», } \\
\text { Пенза }\end{array}$ & Селенопіран & $\begin{array}{c}11 \text { мкг Se; } \\
15 \text { мг вітаміну C; } \\
225 \text { мг вітаміну E }\end{array}$ \\
\hline 3 & Селексен & $\begin{array}{l}\text { ТОВ «Ареал», } \\
\text { Москва }\end{array}$ & $\begin{array}{c}\text { Диметил диімідазолил } \\
\text { селенід }\end{array}$ & 25 мкг Se \\
\hline 4 & НоуСелен & $\begin{array}{c}\text { ТОВ «Іссинга», } \\
\text { Чита }\end{array}$ & Селеніт натрію & $\begin{array}{c}\text { 0,05\%-ний розчин } \\
\text { селеніта натрію в } \\
\text { соляній кислоті } \\
\end{array}$ \\
\hline 5 & БіоСелен & Ростов-на-Дону & $\begin{array}{c}\text { Органічний } \mathrm{Se}, \\
\mathrm{Se}-\text { збагачені пекарські } \\
\text { дріжджі }\end{array}$ & 50 мкг \\
\hline 6 & $\begin{array}{l}\text { Спіруліна- } \\
\text { Сочі-Селен } \\
\end{array}$ & $\begin{array}{c}\text { ТОВ «Еней- } \\
\text { Віта», Москва }\end{array}$ & Se-збагачена спіруліна & 50 мкг Se \\
\hline 7 & Вітасил & & $\begin{array}{c}\text { Автолізат Se-збагачених } \\
\text { дріжджів }\end{array}$ & 50 мкг $\mathrm{Se}$ \\
\hline
\end{tabular}

Більшість науковців вважають за краще застосовувати сполуки, максимально наближені за біосинтезом до Se-цистеїну (Se-метіоніну) 3 метою уникнення небажаних побічних реакцій, які неминучі при багатостадійних синтезах (беруть початок від селенатів і селенітів) i загрожують акумулятивними ефектами.

Аналіз таблиці дозволив виявити ряд недоліків у компонентному складі, технології виробництва, формуванні собівартості готових дієтичних добавок. Наприклад, недоліком способу виробництва БАД 
«Відродження» 3 біоінформаційною сумісністю [2] є відсутність основи для сорбції селену, а також, підвищена концентрація неорганічного селену в добавці (120...160 мг). Це збільшує вірогідність токсикологічного отруєння цим елементом при добовій нормі споживання $55 . .70$ мкг. Недоліками іншого відомого способу виробництва харчової БАД з селеном та дріжджами [3] є обмеженість цільової споживацької аудиторії, оскільки дріжджовмісні добавки протипоказано вживати людям із порушеннями роботи нирок та індивідуальною гіперчутливістю, а також складність технології отримання селеновмісної харчової добавки $\mathrm{i}$, як результат, подорожчання кінцевого продукту. Недоліком способу виробництва мінерального комплексну «Селен Активний» [4] вважаємо лікарську форма випуску добавки, оскільки це унеможливлює використання ії задля збагачення селеном продуктів харчування, а також складність та собівартість виробництва основного компоненту даної добавки - селексену.

Таким чином, актуального значення набуває питання розробки економічно вигідних та, водночас, безпечних дієтичних добавок, основою яких буде білок-Sе система. Саме такими є добавки дієтичні селен-білкові (ДДСБ) «Сивоселен Плюс» та «Неоселен». Білковою складовою ДДСБ $\epsilon$ побічні продукти кисломолочного виробництва (сироватка сирна та підсирна). Доцільність використання сироватки в якості білкової матриці зумовлена наявністю амінокислотних залишків білкового походження та унікальністю мінерального комплексу [5]. Синтез добавки відбувається зарахунок сорбції білками молочної сироватки йонів $\mathrm{Se}$, утворених при дисоціації селенових солей у розчинах протеїнів, та окисно-відновних процесів між ними.

Останні тенденції в галузі науки про харчування пов'язані саме 3 технологією продуктів оздоровчого призначення збагачених на фізіологічно функціональні корисні харчові інгредієнти, що позитивно впливають на здоров’я людини. ДДСБ «Сивоселен Плюс» та «Неоселен» вже мають застосування в галузі харчової промисловості в якості носія органічного селену на переробних підприємствах і підприємствах ресторанного господарства, що забезпечує регулювання селенового обміну та профілактики Se-дефіцитних станів у населення України.

\section{Література:}

1. Применко В.Г. Технології добавок дієтичних селен-білкових та соусів з їх використанням : дис. ... канд. техн. наук : 05.18.16 / Харк. держ. ун-т харчування та торг. Харків, 2019. 330 с.

2. Біологічно активна добавка «Відродження» 3 біоінформаційною сумісністю: декл. пат. 10830 Україна: МПК А61 К 33/04, 33/14, 
33/38. / Яремчук Н. I. №200507075; заявл. 18.07.2005; опубл. 15.11.2005. Бюл. № 11.

3. Спосіб отримання БАД з селеном і дріжджами: декл. пат. 69128 Україна: МПК А 23 L 1/28, С 12 N 1/00, А 61 K 33/04. / Данилова О. I., Решта С. П. № 201110237; заявл. 22.08.2011; опубл. 25.04.2012. Бюл. № 8.

4. Біологічно активна харчова добавка «Мінеральний комплекс 3 селеном «Селен Активний»: декл. пат. 14069 Україна: МПК А $61 \mathrm{~K}$ 33/04. / Василенко О. В., Шамін І. М. №20040503366; заявл. 06.05.2004; опубл. 15.05.2006. Бюл. № 5.

5. Спосіб одержання біологічно активної добавки «Неоселен»: пат. на корисну модель 104883 Україна: МПК А 23 J 1/20, А 61 К 31/095 / Черевк О.І., Головко М.П., Применко В.Г., Головко Т.М.; власник ХДУХТ. № u201507794; заявл. 05.08.2015; опубл. 25.02.2016, Бюл. № 4.

DOI https://doi.org/10.30525/978-9934-588-79-2-2.23

\title{
КОМПЛЕКСНА ОЦІНКА ЯКОСТІ КРЕМОВО-ЗБИВНИХ ЦУКЕРОК 3 ДОДАВАННЯМ НАСІННЯ ЧІА
}

\author{
Шидакова-Каменюка О. Г. \\ кандидат технічних наук, доцент, \\ доцент кафедри технології хліба, кондитерських, \\ макаронних виробів та харчокониентратів
}

Харківського державного університету харчування та торгівлі

Шкляєв О. М.

аспірант кафедри технологї хліба, кондитерських, макаронних виробів та харчокониентратів

Харківського державного університету харчування та торгівлі м. Харків, Украӥна

Рогова А. Л.

кандидат економічних наук, дочент, доцент кафедри технологій харчових виробництв

і ресторанного господарства

Полтавського університету економіки і торгівлі м. Полтава, Україна

Перспективним напрямком розвитку сучасної харчової промисловості є розробка технологій продуктів харчування з поліпшеною хар- 